\title{
Spectroscopic studies of anthracyclines: Structural characterization and in vitro tracking
}

\author{
Zeineb Farhane \\ Technological University Dublin \\ Hugh Byrne \\ Technological University Dublin, hugh.byrne@tudublin.ie \\ Malgorzata Baranska \\ Jagiellonian University Cracow
}

Follow this and additional works at: https://arrow.tudublin.ie/biophonart

Part of the Medicinal Chemistry and Pharmaceutics Commons, Other Biochemistry, Biophysics, and Structural Biology Commons, and the Physics Commons

\section{Recommended Citation}

"Spectroscopic studies of anthracyclines: Structural characterization and in vitro tracking", Ewelina Szafraniec, Katarzyna Majzner, Zeineb Farhane, Hugh J. Byrne, Malgorzata Lukawska, Irena Oszczapowicz, Stefan Chlopicki, Malgorzata Baranska, Spectrochimica Acta Part A: Molecular and Biomolecular Spectroscopy, 169, 152-160 (2016)

This Article is brought to you for free and open access by the DIT Biophotonics and Imaging at ARROW@TU Dublin. It has been accepted for inclusion in Articles by an authorized administrator of ARROW@TU Dublin. For more information, please contact arrow.admin@tudublin.ie, aisling.coyne@tudublin.ie,gerard.connolly@tudublin.ie.

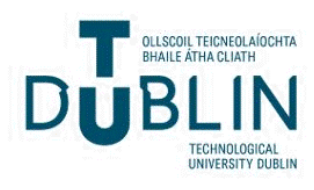




\title{
Spectroscopic studies of anthracyclines: Structural characterization and in vitro tracking
}

\author{
Ewelina Szafraniec $^{\mathrm{a}, \mathrm{b}}$, Katarzyna Majzner ${ }^{\mathrm{a}, \mathrm{b}}$, Zeineb Farhane ${ }^{\mathrm{c}}$, Hugh J. Byrne ${ }^{\mathrm{c}}$, Malgorzata \\ Lukawska $^{\mathrm{d}}$, Irena Oszczapowicz ${ }^{\mathrm{d}}$, Stefan Chlopicki ${ }^{\mathrm{b}, \mathrm{e}}$, Malgorzata Baranska ${ }^{\text {a,b,* }}$ \\ ${ }^{a}$ Faculty of Chemistry, Jagiellonian University, Ingardena 3, Krakow, Poland \\ bJagiellonian Centre for Experimental Therapeutics (JCET), Jagiellonian University, \\ Bobrzynskiego 14, Krakow, Poland \\ ${ }^{c}$ FOCAS Research Institute, Dublin Institute of Technology (DIT), Camden Row, \\ Dublin, Ireland \\ ${ }^{\mathrm{d}}$ Department of Modified Antibiotics, Institute of Biotechnology and Antibiotics, Staroscinska \\ 5, Warsaw, Poland \\ ${ }^{\mathrm{e}}$ Chair of Pharmacology, Jagiellonian University Medical College, Grzegorzecka 16, Krakow, \\ Poland
}

Corresponding author: M. Baranska, baranska@chemia.uj.edu.pl

\begin{abstract}
A broad spectroscopic characterization, using ultraviolet-visible (UV-vis) and Fourier transform infrared absorption as well as Raman scattering, of two commonly used anthracyclines antibiotics (DOX) daunorubicin (DNR), their epimers (EDOX, EDNR) and ten selected analogs is presented. The paper serves as a comprehensive spectral library of UV-vis, IR and Raman spectra of anthracyclines in the solid state and in solution. The particular advantage of Raman spectroscopy for the measurement and analysis of individual antibiotics is demonstrated. Raman spectroscopy can be used to monitor the in vitro uptake and distribution of the drug in cells, using both $488 \mathrm{~nm}$ and $785 \mathrm{~nm}$ as source wavelengths, with submicrometer spatial resolution, although the cellular accumulation of the drug is different in each case. The high information content of Raman spectra allows studies of the drug-cell interactions, and so the method seems very suitable for monitoring drug uptake and mechanisms of interaction with cellular compartments at the subcellular level.
\end{abstract}

\section{Keywords:}

Anthracyclines, UV-Vis spectroscopy, FT-IR spectroscopy, Raman spectroscopy, doxorubicin in vitro, drug- cell interactions 


\section{Introduction}

Anthracyclines are a group of compounds, discovered over 50 years ago, which exhibit cytostatic activity and are used widely in anticancer treatment [1]. The first anthracycline isolated was daunorubicin (also called daunomycin), obtained from a bacterial strain of Streptomyces peucetius [2,3]. Another anthracycline also widely used in oncology is doxorubicin (Adriamycin ${ }^{\circledR}$ ) [4].

Anthracyclines have tetracycline ring structures with a daunosamine group attached by a glycosidic linkage. They are multifunctional derivatives of anthraquinone and are composed of aglycone (4 rings connected to each other - A, B, C, D) and the sugar moiety (Figure 1A). The structure of 7-Deoxydaunorubicinone (7-Deoxy daunorubicinaglycone; DNR-ON) is presented in Figure 1B. Ring B of aglycone is a hydroquinone skeleton and ring C- a quinone group. At the C-4 position of the D-ring, a methoxy group is attached. To an A-ring at the C-9 position, a sugar moiety (daunosamine) is connected via a glycosidic bond at the C-7 position. Daunosamine is derived from 3-amino-2,3,6-trideoxy-L-fructose. The only structural difference between doxorubicin (DOX) and daunorubicin (DNR) is that the side chain of DOX terminates with a primary alcohol (C14), whereas that of DNR terminates with a methyl group [1]. Chemical structures of DOX and DNR are presented in Figure 1A. This small structural difference between DOX and DNR has significant impact on the activity and cytotoxicity of these anthracyclines [1,5].

DNR antitumor activity led to an intensive search for analogs/derivatives compounds, which elicit comparable therapeutic effect but lesser cardiotoxity and vasotoxicity [6]. Within this group of compounds are included DOX and DNR epimers - epidoxorubicin (EDOX) and epidoxorubicin (EDOX) and epidaunorubicin (EDNR; not yet used in the treatment of cancer, EDNR) are semi-synthetic derivatives of DNR and DOX, respectively, obtained by epimerization of the hydroxyl group at C-4' in the daunosamine structure from equatorial to axial positions. Chemical structures of both isomers are shown in Figure 1.A. EDOX is an analog of the second generation, which has been proposed as an alternative to DOX with lower toxicity [7]. 
A
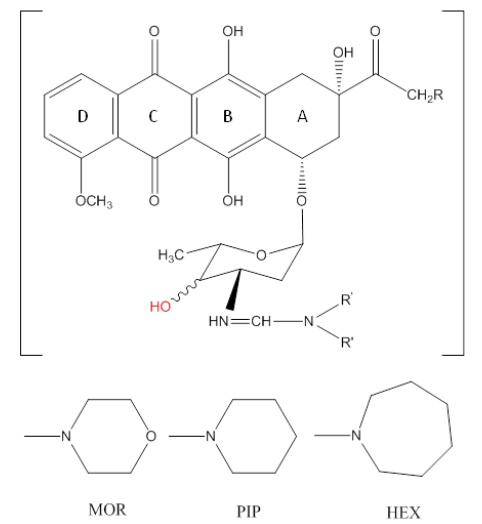

B

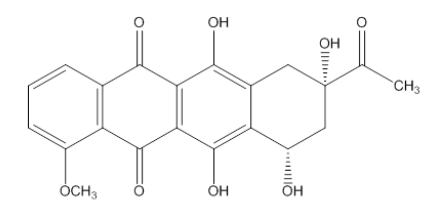

\begin{tabular}{cccc}
\hline & $\mathrm{R}$ & $\mathrm{OH}$ & NR'R' \\
\hline DNR & $\mathrm{H}$ & axial & - \\
EDNR & $\mathrm{H}$ & equatorial & - \\
DOX & $\mathrm{OH}$ & axial & - \\
EDOX & $\mathrm{OH}$ & equatorial & - \\
DNR-FMOR & $\mathrm{H}$ & axial & FMOR \\
EDNR-FMOR & $\mathrm{H}$ & equatorial & FMOR \\
DOX-FMOR & $\mathrm{OH}$ & axial & FMOR \\
EDOX-FMOR & $\mathrm{OH}$ & equatorial & FMOR \\
DNR-FPIP & $\mathrm{H}$ & axial & FPIP \\
EDNR-FPIP & $\mathrm{H}$ & equatorial & FPIP \\
DOX-FPIP & $\mathrm{OH}$ & axial & FPIP \\
EDOX-FPIP & $\mathrm{OH}$ & equatorial & FPIP \\
DNR-FHEX & $\mathrm{H}$ & axial & FHEX
\end{tabular}

C

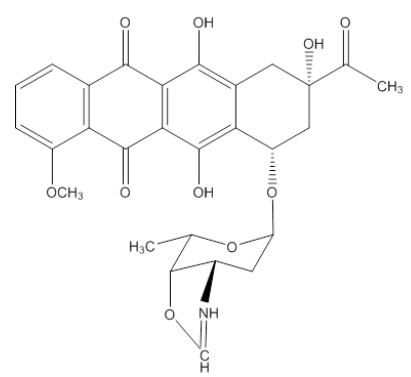

Figure1.A: Chemical structures of doxorubicin and daunorubicin derivatives; B: 7 Deoxydaunorubicinone; C: oxazolinodaunorubicin (DNR-OXZL).

Despite the broad and relatively established usage of DNR, DOX, EDOX in antitumor therapy, their mechanism of action is still not fully understood. Anthracyclines belong to the anticancer cycle-dependent and phase-specific drugs [1]. They have a complex mechanism of action, which includes: intercalation into DNA, inhibition of the synthesis of macromolecules, formation of bonds between the nitrogenous bases of DNA, DNA alkylation, DNA crosslinking, inhibition of topoisomerase I and II - key enzymes in DNA synthesis, and formation of free radicals, which damage DNA and lead to lipid peroxidation $[1,8]$. Initiation of DNA damage through the inhibition of topoisomerase II, leading to the apoptosis, is believed to be a dominant mechanism of therapeutic action of the anthracyclines [8-10] as well as of their cardiotoxicity mediated by topoisomerase-II $\beta$ in cardiomyocytes [11]. Topoisomerases are enzymes, which cause the double helix of DNA to be untangled or unwound, a process which is necessary for DNA replication and transcription. Inhibition of topoisomerase II in cancer cells consists of the formation of the complex of anthracycline-DNA-topoisomerase II, 
resulting in DNA fragmentation and, as a consequence, in the inhibition of cellular proliferation and cell death $[1,8,9]$.

Anthracycline therapy is complicated by its cardiotoxicity, which can in some cases lead to symptomatic heart failure, and even death caused by cardiac diseases (Torti et al. 1986; Wu 2002; Minotti et al. 2004b; Cortés-Funes and Coronado 2007; Cardinale et al. 2010; Smith et al. 2010; Sawyer et al. 2010; Toldo et al. 2013). These complications can occur both during active anti-cancer therapy (so called early cardiotoxicity), within one year after the end of treatment, and many years after the end of therapy with anthracyclines $[18,19]$.

Cardiotoxicity and side effects of anthracycline therapy spurred researchers worldwide to explore analogs/derivatives of the parent drugs, especially since EDOX and EDNR have demonstrated improved performance in terms of balance of antitumor active versus cardiotoxicity. Modifications in the chemical structure by, for example replacement of the$\mathrm{NH}_{2}$ moiety at position $3^{\prime}$ in daunosamine by a formamidine group $\left(-\mathrm{N}=\mathrm{CH}-\mathrm{NR}{ }^{1} \mathrm{R}^{2}\right)$, which includes other cyclic amines of gradually increased ring size, for example piperidine $\left(-N R^{1} R^{2}\right.$ is -FPIP), morpholine (-NR ${ }^{1} R^{2}$ is -FMOR) or hexamethyleneimine $\left(-N R^{1} R^{2}\right.$ is -FHEX) $[20,21]$ lead to the formation of new and promising anthracycline analogs (formamidinoanthracyclines). Chemical structures of these selected derivatives are also presented in Figure 1.A. It has been shown that these new derivatives of anthracyclines exhibit lower toxicity and cardiotoxicity, together with an ability to overcome the barrier of drug resistance in vitro, as well as high anticancer activity in comparison to the parent compounds (DNR, DOX, EDNR and EDOX) [10,20,22]. Another interesting analog of anthracycline antibiotics is a derivative of DNR - oxazolinodaunorubicin (DNR-OXZL) [23]. DNR-OXZL contains an oxazoline ring connected to the daunosamine moiety and seems to display improved properties (higher anticancer efficacy, lower cardiotoxicity, etc.) than DNR [23].

As these new compounds emerge, it is important to effectively characterize their structures, but also their efficacies and mechanisms of interaction and ultimately generate quantitative structure activity relationships, as a basis for predictive toxicological models to guide synthetic strategy. Anthracyclines, especially DNR and DOX have been widely investigated using various spectroscopic methods, e.g. Raman spectroscopy [24,25], Resonance Raman (RR) [26-28], Surface Enhanced Raman Spectroscopy (SERS) [29-32], UV-Vis absorption $[26,33]$ and FT-IR absorption spectroscopy [24,34,35]. The visible absorption spectra of DOX and DNR are, however, almost identical, having a maximum of absorption near to 480-490 nm. 
Vibrational spectroscopy seems to be the most appropriate technique to better understand the molecular chemical structures and the interactions of these compounds with DNA [29,36]. The strong visible absorption maxima can be easily used to exploit the benefits of resonance enhancement in Raman spectroscopy. The resonance and pre-resonance Raman spectra of DOX and DNR are related to the first electronic band at $480 \mathrm{~nm}$ and complete band assignments have been documented [27,28].

Over the past decades, the potential of vibrational spectroscopy for biomedical applications has been well established [37-40]. Raman spectroscopy coupled with confocal microscopy has a great potential for biomedical and biopharmaceutical applications due to ability of noninvasive, label-free detection of cellular changes at single cell level and imaging biomolecule distribution in an individual cell [41,42]. The high information content of Raman spectra can be used to characterize drug-cell interactions $[43,44]$ and therefore serve as a suitable tool for drug screening.

In this paper, we present spectroscopic characterization (UV-vis, FT-IR, Raman (RS) and Resonance Raman (RRS) spectroscopies) of the most common anthracyclines (DOX, DNR), their epimers (EDOX, EDNR) and ten selected analog (four morpholine (-FMOR) compounds, four piperidine (-FPIP) compounds, one hexamethyleneimine derivative of DNR (DNR-FHEX) and oxazolinodaunorubicin (DNR-OXZL)). This work shows the potential of Raman spectroscopy for the measurement and analysis of such a large collection of individual and structurally similar anthracycline antibiotics and their analogs. It can serve as a comprehensive vibrational spectral library, based on previously reported UV-vis, IR and Raman measurements. Several reviews have previously been resented (e.g.[24,27,45,46]), showing the potential of Raman spectroscopy, but they were mostly based on the resonance effect, (and IR spectroscopy [24]) for the measurement and analysis of DOX and DNR. However, to the best of our knowledge, such a large collection of individual anthracycline compounds Raman spectra has not been provided and discussed in any paper. Additionally, Raman spectroscopy, can be used to monitor the in vitro uptake and distribution of drug carrier systems and the drug itself [47]. Here, we present the approach that comprises full spectral characterization of several chemotherapeutic agents and in vitro subcellular tracking of a known anthracycline compound (DOX) based on its unique spectral features.

\section{Experimental}

\subsection{Anthracyclines samples}


All investigated anthracycline compounds, of purity $>97.5 \%$ as determined using HPLC, were synthesized in the Institute of Biotechnology and Antibiotics, Warsaw, Poland and synthetized as described previously [20,22].

\subsection{Cell culture}

EA.hy926 cells were cultured at $37^{\circ} \mathrm{C}$ and $5 \% \mathrm{CO}_{2}$ in Dulbecco's modified Eagle's medium (DMEM, Lonza) supplemented with 10\% fetal bovine serum (FBS),1\% penicillinstreptomycin, $2 \mathrm{mM} \mathrm{L-Glutamine} \mathrm{(Invitrogen)} \mathrm{and} \mathrm{2 \%} \mathrm{HAT} \mathrm{medium} \mathrm{supplement.} \mathrm{The} \mathrm{cell}$ cultures were incubated in a $37{ }^{\circ} \mathrm{C}, 5 \% \mathrm{CO}_{2} / 95 \%$ air, humidified cell culture incubator and passaged three times a week. For Raman measurements, cells (EA.hy926) were cultivated on calcium fluoride slides $\left(\mathrm{CaF}_{2}, 25 \times 2 \mathrm{~mm}\right.$, Pike Technologies, U.S.) placed within wells of a 6well plate and fed with complete medium containing either no anthracycline (control) or $1 \mu \mathrm{M}$ DOX. After 24 hours, the cells were fixed with $2.5 \%$ glutaraldehyde (4 min) and stored in isotonic phosphate buffer $\left(\mathrm{pH}=7 ; 4^{\circ} \mathrm{C}\right)$, until the start of data acquisition.

A549 human lung adenocarcinoma cells were cultured in DMEM supplemented with $2 \mathrm{mM} \mathrm{L}$-glutamine and $10 \% \mathrm{FBS}$ at $37^{\circ} \mathrm{C}$ in a humidified atmosphere containing $5 \% \mathrm{CO}_{2}$ and passaged every two days. For Raman measurements, cells (A549) were seeded on $\mathrm{CaF}_{2}$ disks for $24 \mathrm{hrs}$, after which medium was completely removed and cells were washed twice with PBS and fed with complete medium containing either no anthracycline (control) or $1 \mu \mathrm{M}$ DOX. After 24 hours incubation, the cells were fixed with formalin $(4 \%, 15 \mathrm{~min})$ and kept in PBS until the start of measurement.

\section{3. $U V$-vis spectroscopy}

UV-vis spectra of sample solutions were measured in quartz cells with a path length of $1 \mathrm{~cm}$ in the 190-750 nm spectral range using a Perkin Elmer Lambda-35 spectrometer. UVvis spectra were recorded using a scanning speed of $480 \mathrm{~nm} \mathrm{~min}^{-1}$ with a $1 \mathrm{~nm}$ data interval.

\subsection{FT-IR spectroscopy}


FT-IR spectra of sample powders were obtained using a Bruker Alpha FT-IR spectrometer in Attenuated Total Reflection (ATR) mode, over the spectral range 400-4000

$\mathrm{cm}^{-1}$. For optimal signal-to-noise ratio, 128 scans were averaged per sample spectrum and 256 scans per background spectrum.

\subsection{Raman spectroscopy}

Anthracyclines samples

Raman spectra were acquired using a WITec Raman microscope, with application of a 20x air objective $(\mathrm{NA}=0.45)$. Two excitation wavelengths were used: $488 \mathrm{~nm}$ (spectral range: $0-4345 \mathrm{~cm}^{-1}$, laser power: $1.16 \mu \mathrm{W}$ ) and $785 \mathrm{~nm}$ (spectral range: $0-3200 \mathrm{~cm}^{-1}$, laser power: $246.5 \mathrm{~mW}$ ). Solid state samples of anthracyclines as well as solution drops were deposited on calcium fluoride slides for measurements. 10-20 scans, with integration times of 2-5 s per scan for source wavelength $785 \mathrm{~nm}$, and 15-30 scans, with integration times of 1-5 s per scan for source wavelength $488 \mathrm{~nm}$, were collected and averaged. Pre-processing, including cosmic spike removal and background subtraction (using a polynomial fit, order 4) was performed using the WITec Project Plus software.

Cells

EA.hy926 cells Raman mapping was done using a WITec Raman microscope (WITec alpha300 R, Ulm, Germany) with the application of a $60 \times$ water immersion objective (Nikon Fluor, NA =1). Excitation wavelength of $488 \mathrm{~nm}$ was used due to a high lateral resolution. A total exposure time was ca. 40-60 min per cell (integration time of 0.7 second per spectrum). Pre-processing included cosmic spike removal and background subtraction was performed using Witec Project Plus software.

A549 human lung adenocarcinoma cells were measured using Horiba Jobin-Yvon LabRAM HR800 spectrometer with $785 \mathrm{~nm}$ laser as a source. Spectra were acquired using 100x objective (LCPlanN, Olympus) with integration time of 30 second per spectrum two times, from three cell locations: cytoplasm, nucleus and nucleolus, to finally produce a data set of 28 points per cell locations for each control and exposure to DOX cells.

\section{Results and discussion}




\section{1. $U V$-vis spectroscopy}

Spectral profiles of all UV-vis spectra shown are similar, with the exception of that of DNR-HEX (also DNR-OXZL and DNR-ON, due to use of different solvent), and the absorption spectra show maxima at 232, 252, 290 and $480 \mathrm{~nm}$ (Figure 2). The maximum at $480 \mathrm{~nm}$ is assigned to a $\pi-\pi^{*}$ transition of the quinonoid structure [27]. The UV-Vis spectrum of DNR-HEX can be distinguished by higher intensity of the bands at 195 and $256 \mathrm{~nm}$ and the absence of the band at $290 \mathrm{~nm}$. Although they do not provide an easily distinguishable spectral fingerprint of the specific compound, at the spectral profile is dominated by the $\pi$ conjugated electronic system, common to all compounds, UV-vis spectra give useful information in terms of choosing the source wavelength for Raman spectroscopy measurements. The Raman spectra of anthracyclines obtained with an excitation within the electronic band at $480 \mathrm{~nm}$ can result in resonance or pre-resonance.

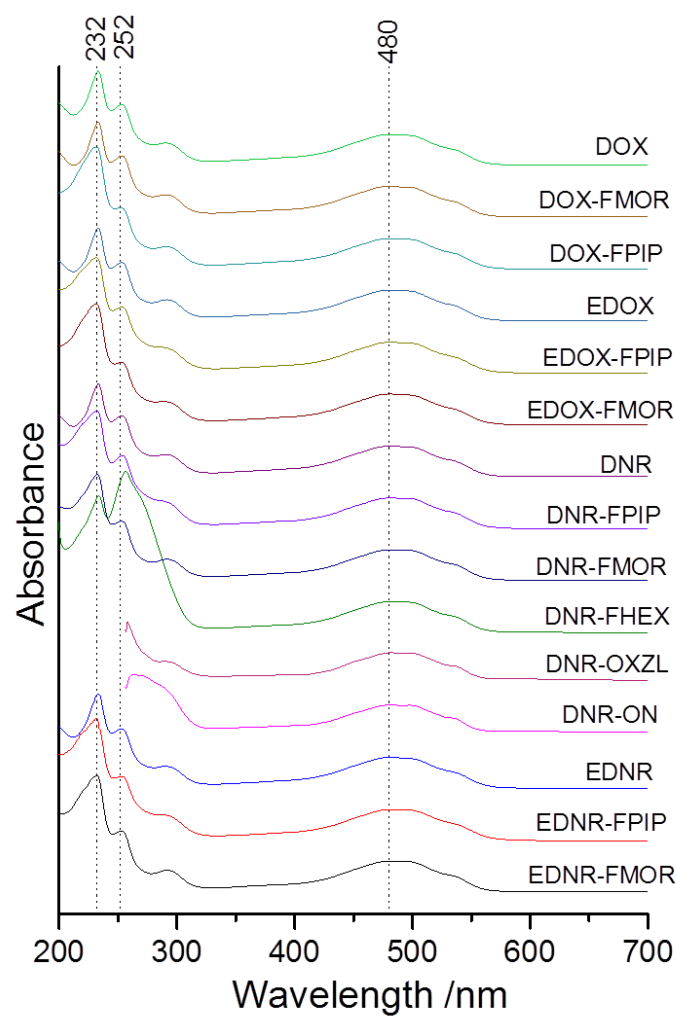


Figure 2. UV-vis spectra of investigated anthracyclines in water solution (for DNR-ON and DNR-OXZL due to high absorbance of DMSO used as a solvent the $200-260 \mathrm{~nm}$ region is not shown).

\subsection{FT-IR spectroscopy}

FT-IR spectra of 15 studied anthracyclines over the spectral range of $500-2000 \mathrm{~cm}^{-1}$ are presented in Figure 3. A spectral signature of each anthracycline is clearly evident, and therefore it is possible to uniquely identify the investigated compounds. However, lack of sufficient literature data together with the complex molecular structure of anthracyclines encumbers the assignment of bands observed in acquired spectra. The assignment of spectral bands proposed here is made according to [24].

Despite the complexity of the fingerprint of anthracyclines, there are several characteristic bands present in each illustrated spectrum. Bending vibrations of $\mathrm{C}=\mathrm{O}$ and $\mathrm{C}-\mathrm{OH}$ of anthraquinone are observed in all spectra presented in Figure 3 in the range of $978-1000 \mathrm{~cm}^{-1}$, as well as bands between $1111-1120 \mathrm{~cm}^{-1}$, assigned to ring breathing coupled with $\mathrm{C}-\mathrm{C}=\mathrm{O}$ group bending vibrations. Another characteristic band is present in the range of 1274-1286 $\mathrm{cm}^{-1}$ and can be assigned to hydrogen bond bending vibrations $\left(\delta \mathrm{O}-\mathrm{H}^{\cdots} \mathrm{O}\right)$ with contributions of ring vibrations. Bands attributed to ring vibrations are also observed in the range of 1573$1582 \mathrm{~cm}^{-1}$ and 1613-1625 $\mathrm{cm}^{-1}$. Additionally, a strong, isolated carbonyl band in the range of $1690-1730 \mathrm{~cm}^{-1}$ is present in each collected infrared spectrum of studied anthracyclines. Detailed assignments of observed bands are listed in Table 1, the most characteristic ones being highlighted. 


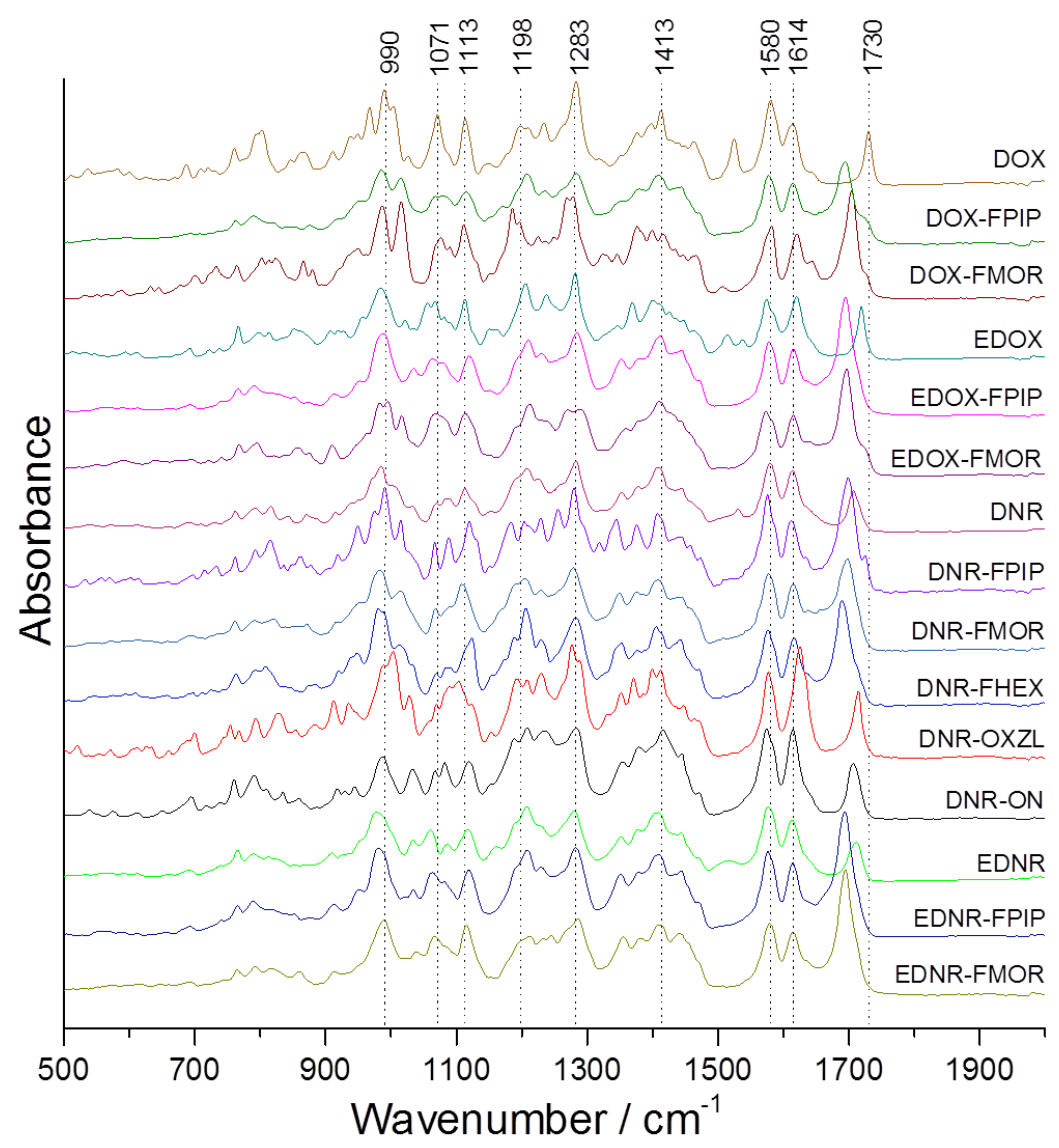

Figure 3. FT-IR spectra of investigated anthracyclines in the solid state. 
Table 1. An assignment of FT-IR bands of investigated anthracyclines in the solid state. Grey lines show the most characteristic bands.

\begin{tabular}{|c|c|c|c|c|c|c|c|c|c|c|c|c|c|c|c|}
\hline Assignment & DOX & $\begin{array}{l}\text { DOX- } \\
\text { FPIP }\end{array}$ & $\begin{array}{l}\text { DOX- } \\
\text { FMOR }\end{array}$ & EDOX & $\begin{array}{l}\text { EDOX- } \\
\text { FPIP }\end{array}$ & $\begin{array}{l}\text { EDOX- } \\
\text { FMOR }\end{array}$ & DNR & $\begin{array}{l}\text { DNR- } \\
\text { FPIP }\end{array}$ & $\begin{array}{l}\text { DNR- } \\
\text { FMOR }\end{array}$ & $\begin{array}{l}\text { DNR- } \\
\text { FHEX }\end{array}$ & $\begin{array}{l}\text { DNR- } \\
\text { OXZL }\end{array}$ & DNR-ON & EDNR & $\begin{array}{l}\text { EDNR- } \\
\text { FPIP }\end{array}$ & $\begin{array}{l}\text { EDNR- } \\
\text { FMOR }\end{array}$ \\
\hline $\begin{array}{l}\text { 8C-H, CO-C (a- } \\
\text { d), O-C-O (a-d) }\end{array}$ & $948(w)$ & - & $949(w)$ & - & $952(w)$ & - & - & $949(\mathrm{~m})$ & - & $949(\mathrm{~m})$ & $935(\mathrm{~m})$ & 944(v) & - & - & - \\
\hline $\begin{array}{l}\text { C- }-\mathrm{C}(\mathrm{d}), \\
\mathrm{C}-\mathrm{OH}(\mathrm{d}), \delta \mathrm{C}-\mathrm{O} \\
\text { (d) }\end{array}$ & $967(m)$ & - & - & $957(w)$ & - & $963(w)$ & - & - & - & - & $998(w)$ & - & - & $951(w)$ & - \\
\hline $\begin{array}{c}\mathrm{C}-\mathrm{H}_{2} \text { (a), } \delta \mathrm{C}=\mathrm{O}, \\
\delta \mathrm{C}-\mathrm{OH} \text { (a) }\end{array}$ & 990(s) & $986(\mathrm{~s})$ & $986(\mathrm{~s})$ & $984(\mathrm{~s})$ & 989(s) & $990(\mathrm{~s})$ & $985(\mathrm{~s})$ & 990(s) & 983(s) & $980(\mathrm{~s})$ & $1003(\mathrm{~s})$ & $988(\mathrm{~s})$ & $978(\mathrm{~s})$ & 979(s) & 989(s) \\
\hline $\begin{array}{l}\text { vC-O-C (a-d), } \\
\text { vC-OH (a), }\end{array}$ & $1004(\mathrm{~m})$ & 1015(s) & 1015(s) & $1022(w)$ & $1034(\mathrm{~m})$ & $1016(\mathrm{~m})$ & & $1015(\mathrm{~m})$ & $1015(\mathrm{~m})$ & $1013(\mathrm{~m})$ & $1028(\mathrm{~m})$ & $1033(\mathrm{~m})$ & $1034(w)$ & $1034(w)$ & $1038(\mathrm{w})$ \\
\hline $\begin{array}{c}\delta \mathrm{C}-\mathrm{OH}(\mathrm{a}) \\
\delta \mathrm{C}-\mathrm{C}=\mathrm{O}, \delta \mathrm{C}-\mathrm{H}(\mathrm{a})\end{array}$ & $1071(\mathrm{~m})$ & $1075(\mathrm{~m})$ & $1076(\mathrm{~m})$ & $1068(\mathrm{~m})$ & $1063(\mathrm{~m})$ & 1069(s) & $1084(\mathrm{~m})$ & $1067(\mathrm{~m})$ & $1068(\mathrm{~m})$ & $1070(w)$ & $1070(\mathrm{~m})$ & $1068(\mathrm{~m})$ & $1061(\mathrm{~m})$ & $1063(\mathrm{~m})$ & $1067(\mathrm{~m})$ \\
\hline $\begin{array}{c}\text { v ring, } \omega \mathrm{C}-\mathrm{H}_{2}(\mathrm{a}), \\
\omega \mathrm{C}-\mathrm{H}_{3}(\mathrm{~d})\end{array}$ & - & - & - & - & $1080(\mathrm{~m})$ & - & - & $1088(\mathrm{~m})$ & - & $1090(w)$ & $1090(\mathrm{~m})$ & $1082(\mathrm{~m})$ & $1086(w)$ & 1081(w) & - \\
\hline $\begin{array}{l}\text { Ring breathing, } \\
\delta \mathrm{C}-\mathrm{C}=\mathrm{O}(\mathrm{a}) \\
\mathrm{C}-\mathrm{H}_{3}(\mathrm{a})\end{array}$ & $1113(\mathrm{~m})$ & $1115(\mathrm{~m})$ & $1111(\mathrm{~m})$ & $1113(\mathrm{~m})$ & $1120(\mathrm{~m})$ & 1113(s) & $1113(\mathrm{~m})$ & $1119(\mathrm{~m})$ & 1109 (s) & $1124(\mathrm{~m})$ & $1120(\mathrm{~m})$ & $1119(\mathrm{~m})$ & $1118(\mathrm{~m})$ & $1118(\mathrm{~m})$ & $1115(\mathrm{~s})$ \\
\hline $\begin{array}{c}\mathrm{C}-\mathrm{H}_{2}(\mathrm{~d}), \mathrm{C}-\mathrm{H}(\mathrm{d}), \\
\mathrm{O}-\mathrm{H}(\mathrm{d}), \mathrm{C}-\mathrm{O}-\mathrm{C} \\
\text { (d) }\end{array}$ & $1198(m)$ & $1208(\mathrm{~s})$ & $1186(\mathrm{~s})$ & $1205(\mathrm{~m})$ & $1210(\mathrm{~m})$ & $1211(\mathrm{~s})$ & $1208(\mathrm{~m})$ & $1204(\mathrm{~m})$ & $1205(\mathrm{~m})$ & $1206(\mathrm{~s})$ & $1205(\mathrm{~m})$ & $1209(\mathrm{~m})$ & $1208(\mathrm{~s})$ & $1209(\mathrm{~s})$ & $1212(\mathrm{~m})$ \\
\hline$\delta \mathrm{CO}-\mathrm{H}$ & $1233(\mathrm{~m})$ & $1235(\mathrm{~s})$ & $1225(\mathrm{~m})$ & $1238(\mathrm{~m})$ & $1230(\mathrm{~m})$ & - & $1225(\mathrm{w})$ & $1255(\mathrm{~m})$ & $1229(\mathrm{~m})$ & $1229(\mathrm{~m})$ & $1230(\mathrm{~m})$ & $1236(\mathrm{~s})$ & & $1230(\mathrm{~m})$ & $1245(\mathrm{~m})$ \\
\hline $\begin{array}{l}\delta \mathrm{O}-\mathrm{H}^{*} \mathrm{O} \text {, Ring, } \\
\text { ouC- } \mathrm{H}_{2}(\mathrm{~d})\end{array}$ & $1283(\mathrm{~s})$ & $1283(\mathrm{~s})$ & 1274(s) & $1281(\mathrm{~s})$ & $1284(\mathrm{~s})$ & $1289(\mathrm{~m})$ & $1283(\mathrm{~s})$ & $1280(\mathrm{~s})$ & $1278(\mathrm{~s})$ & $1282(\mathrm{~s})$ & $1276(s)$ & $1283(\mathrm{~s})$ & $1280(\mathrm{~s})$ & $1282(\mathrm{~s})$ & $1286(\mathrm{~s})$ \\
\hline $\begin{array}{c}\delta \mathrm{O}-\mathrm{H}^{\cdots} \mathrm{O} \text {, ring, } \mathrm{C}- \\
\mathrm{H}_{2} \text { (a) }\end{array}$ & - & - & $1346(w)$ & $1346(w)$ & 1352(m) & - & $1353(\mathrm{~m})$ & $1344(\mathrm{~m})$ & $1349(\mathrm{~m})$ & $1352(\mathrm{~m})$ & $1351(\mathrm{~m})$ & $1354(\mathrm{~m})$ & $1351(\mathrm{~m})$ & $1351(\mathrm{~m})$ & $1355(\mathrm{~m})$ \\
\hline $\begin{array}{c}\delta \mathrm{C}-\mathrm{H}(\mathrm{a}), \delta \mathrm{O}- \\
\mathrm{H}^{\cdots}{ }^{*} \mathrm{O}, \delta \mathrm{C}-\mathrm{C}\end{array}$ & $1376(m)$ & 1379(m) & $1376(\mathrm{~m})$ & $1369(\mathrm{~m})$ & 1379(w) & $1360(\mathrm{~m})$ & $1377(\mathrm{~m})$ & $1375(\mathrm{~m})$ & $1375(\mathrm{~m})$ & $1376(w)$ & $1371(\mathrm{~m})$ & $1379(\mathrm{~m})$ & $1377(\mathrm{~m})$ & $1378(\mathrm{~m})$ & $1382(\mathrm{~m})$ \\
\hline Ring, C-H(aro) & $1413(\mathrm{~s})$ & $1409(\mathrm{~s})$ & $1416(\mathrm{~m})$ & $1400(\mathrm{~m})$ & $1412(\mathrm{~s})$ & $1410(\mathrm{~s})$ & $1409(\mathrm{~s})$ & $1407(\mathrm{~m})$ & $1409(\mathrm{~s})$ & $1405(\mathrm{~s})$ & 1412(s) & $1416(\mathrm{~s})$ & $1409(\mathrm{~s})$ & $1410(\mathrm{~s})$ & 1411(s) \\
\hline Ring, $\delta \mathrm{C}-\mathrm{H}_{3}$ (a) & $1462(\mathrm{~m})$ & 1443(m) & $1465(w)$ & $1462(w)$ & $1444(\mathrm{~m})$ & - & $1444(\mathrm{~m})$ & $1439(w)$ & $1443(\mathrm{~m})$ & $1442(\mathrm{~m})$ & $1447(\mathrm{~m})$ & $1444(\mathrm{~m})$ & $1443(\mathrm{~m})$ & $1444(\mathrm{~m})$ & 1441(m) \\
\hline $\begin{array}{l}\delta \mathrm{C}-\mathrm{H}_{2}(\mathrm{a}) \\
\delta \mathrm{CO}-\mathrm{H}(\mathrm{a})\end{array}$ & $1524(\mathrm{~m})$ & - & $1507(w)$ & $1515(\mathrm{w})$ & - & - & $1531(\mathrm{w})$ & - & - & - & - & - & $1515(\mathrm{w})$ & - & - \\
\hline vRing, $\delta \mathrm{C}-\mathrm{H}(\operatorname{aro})$ & $1578(\mathrm{~s})$ & $1577(\mathrm{~s})$ & $1582(\mathrm{~s})$ & $1574(\mathrm{~s})$ & $1577(\mathrm{~s})$ & $1573(\mathrm{~s})$ & $1579(\mathrm{~s})$ & $1576(\mathrm{~s})$ & $1577(\mathrm{~s})$ & $1576(\mathrm{~s})$ & $1576(\mathrm{~s})$ & $1574(\mathrm{~s})$ & $1576(s)$ & $1576(\mathrm{~s})$ & $1578(\mathrm{~s})$ \\
\hline $\begin{array}{l}\text { Ring breathing, } \\
\text { ring (Phe) }\end{array}$ & $1614(m)$ & $1615(\mathrm{~s})$ & $1620(\mathrm{~m})$ & $1620(\mathrm{~s})$ & $1615(3)$ & $1615(\mathrm{~s})$ & 1614(s) & $1612(\mathrm{~m})$ & $1616(\mathrm{~s})$ & $1616(\mathrm{~s})$ & $1625(\mathrm{~s})$ & $1614(\mathrm{~s})$ & 1613(m) & $1614(\mathrm{~m})$ & $1615(\mathrm{~m})$ \\
\hline $\mathrm{vC}=\mathrm{O}, \delta \mathrm{C}-\mathrm{H}_{2}(\mathrm{a})$ & $1730(\mathrm{~m})$ & 1694(s) & 1704(s) & $1719(\mathrm{~m})$ & $1695(\mathrm{~s})$ & $1697(\mathrm{~m})$ & $1707(\mathrm{~s})$ & $1698(\mathrm{~s})$ & $1698(\mathrm{~s})$ & $1689(\mathrm{~s})$ & $1714(\mathrm{~m})$ & $1707(\mathrm{~s})$ & $1711(\mathrm{~m})$ & 1694(s) & 1694(s) \\
\hline
\end{tabular}

$v, \delta, \omega$, ou - belong to the stretching, bending, wagging vibrations;

a- antraquinonepart, d- daunosamine part

$s, m, w$-strong, medium, weak intensity of bands 


\subsection{Raman spectroscopy}

Non resonant Raman spectra of solid state anthracyclines were acquired with $785 \mathrm{~nm}$ source wavelength in the spectral range of $290-2000 \mathrm{~cm}^{-1}$ (Figure 4). They show characteristic spectral profiles with several marker bands (Table 2, the assignment of bands was performed based on literature [24,27]). Bands at $\sim 344 \mathrm{~cm}^{-1}$ can be attributed to carbonyl coupled with ring bending [27] or ring bending and $\mathrm{C}-\mathrm{O}-\mathrm{H}$ wagging vibrations of the side chain of DOX [24]. The presence of this primary alcohol is the only structural difference between DOX and DNR as well as between EDOX and EDNR.

Strong bands at 444 and $462 \mathrm{~cm}^{-1}$ have comparable intensity in the DOX spectrum. Both can be assigned to ring and carbonyl group bending vibrations [24,27]. The intensity ratio of the 444 and $462 \mathrm{~cm}^{-1}$ bands changes among the spectra of all investigated compounds. The 444 $\mathrm{cm}^{-1}$ band can be observed with a strong intensity for all anthracyclines except for EDOX, while the $462 \mathrm{~cm}^{-1}$ band is diminished in spectra of EDNR and its derivatives, DNR, DNRFMOR, EDOX-FPIP, DOX-FPIP and DOX-FMOR, although not so for EDOX. A weak band at $792 \mathrm{~cm}^{-1}$ is assigned to the ring bending vibration and $\mathrm{C}-\mathrm{H}_{3}$ wagging vibration of the daunosamine moiety [24]. This band is present in DOX, DNR and spectra of their derivatives. However, it disappears for EDOX, EDNR and their derivatives. This can be correlated with the equatorial position of the hydroxyl group at C-4' in the daunosamine moiety. The band at this wavenumber is also not evident in the spectrum of DNR-ON (7-Deoxydaunorubicinone; a DNR derivative with no sugar moiety). Another characteristic band located at $1083 \mathrm{~cm}^{-1}$ is attributed to ring breathing and an aromatic carbon hydrogen bending, although an alternative assignment is to the methoxy carbon-oxygen stretch [27]. Hydroxyanthraquinones typically show two or three bands in the $1200-1300 \mathrm{~cm}^{-1}$ region due to coupled phenolic carbon-oxygen stretching and oxygen-hydrogen bending [28]. In the DOX spectrum, there are three bands present in this region at 1205,1235 and $1290 \mathrm{~cm}^{-1}$, all attributed to hydrogen bond bending vibrations $\left(\mathrm{O}-\mathrm{H}^{\cdots} \mathrm{O}\right)$ [24]. Additionally, bands at 1205 and $1290 \mathrm{~cm}^{-1}$ are assigned to ring vibration; bending of C-O-H groups contribute at $1235 \mathrm{~cm}^{-1}$ [24,27]. All three bands are present in the Raman spectrum of each compound studied, suggesting a common origin. Bands in the 1410-1455 $\mathrm{cm}^{-1}$ region can be assigned to aromatic ring vibrations [24]. There are three bands observed for DOX at 1413, 1428 and $1455 \mathrm{~cm}^{-1}$, similar to DOX-FMOR, EDOX, DNR-FPIP and DNR-OXZL. However, spectra of other investigated compounds show one strong band at $\sim 1440 \mathrm{~cm}^{-1}$ with a shoulder at $\sim 1413 \mathrm{~cm}^{-1}$ in this region. Raman features at 1579 and $1643 \mathrm{~cm}^{-1}$ (DOX) originate from ring vibrations [24]. However, bands at 
1428, 1455 and $1579 \mathrm{~cm}^{-1}$ can be assigned to aromatic $\mathrm{C}=\mathrm{C}$ stretch coupled with stretch vibrations of hydrogen bonded carbonyl [27]. Similarly, a band located at $1643 \mathrm{~cm}^{-1}$ is attributed to hydrogen bonded stretching of $\mathrm{C}=\mathrm{O}$ [27].

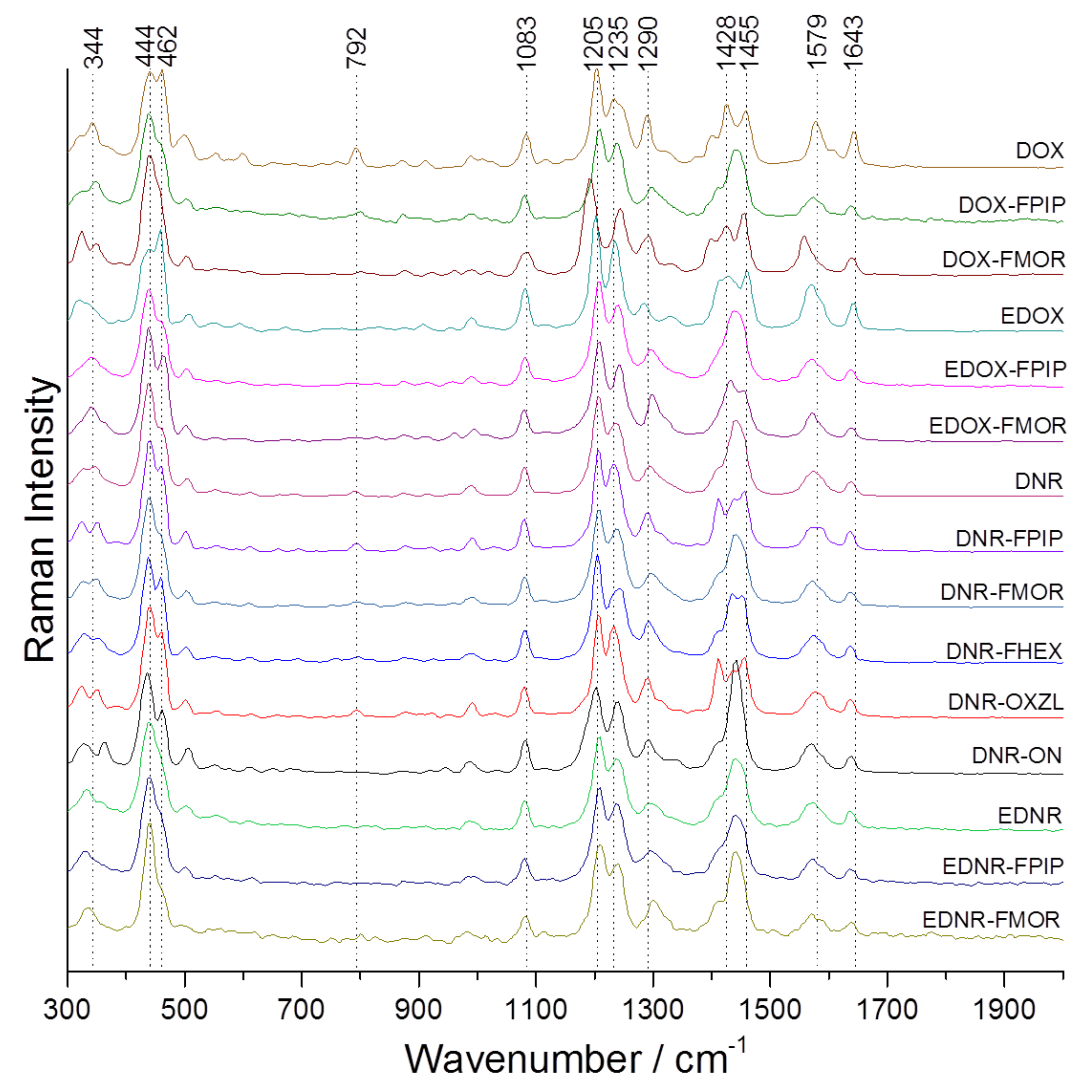

Figure 4. Raman spectra of investigated anthracyclines in the solid state ( $785 \mathrm{~nm}$ source).

In terms of in vitro studies, studies of anthracyclines were used in a form of solutionin solubilised form are more appropriate, as they are exposed to, and uptaken by, the cells in this form., and apposite Raman measurements were performed.For this purpose, water-aqueous solutions of almost all investigated compounds were measured, except DNR-ON and DNROXZL, where-for which DMSO was used as solvent. Raman spectra obtained for compounds studied in solution with a source wavelength of $785 \mathrm{~nm}$ (Figure 5) share theexhibit comparable spectral profiles as-to those obtained for the solid state anthracyclines (Figure 4), indicating a minimal effect of aggregation on the molecular degrees of freedom, although some differences are evident. As expected, in solutionThe solid state microcrystalline environment can cause splitting and dampening of some peaks, bands are broadened and 


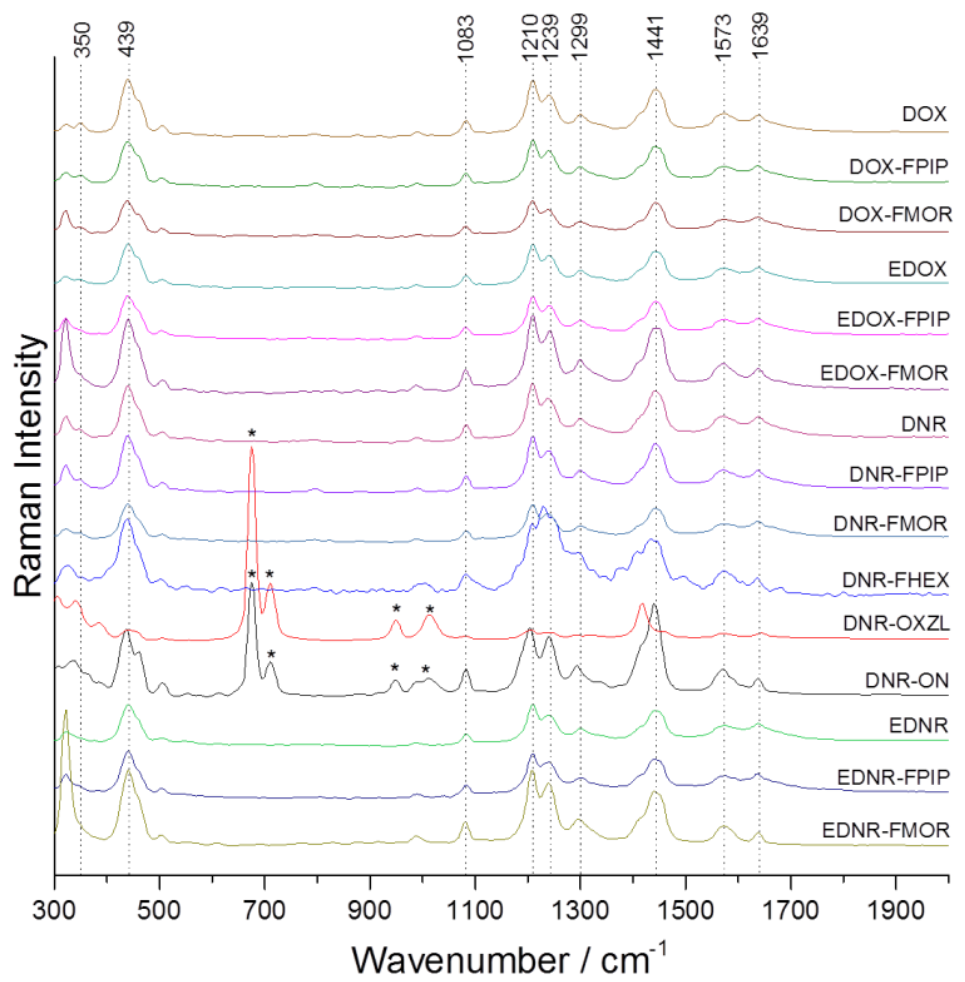

Figure 5. Raman spectra of anthracyclines in the liquid state (785 nm source). Bands marked with * originate from DMSO used as a solvent.

Generally, as can be seen in Table 2, bands characteristic for anthracycline and their derivatives are mainly related to the highly polarizable ring derived vibrations and not the substituents themselves. The position of individual modes for investigated derivatives is shifted only a few $\mathrm{cm}^{-1}$ between the compounds. More significant changes are observed for FT-IR spectra. However, this method is limited when applied for in vitro study, as discussed later in Section 3.4. 
Table 2. An assignment of Raman bands of investigated anthracyclines in the solid state (785 nm excitation line). Grey lines show the most characteristic bands.

\begin{tabular}{|c|c|c|c|c|c|c|c|c|c|c|c|c|c|c|c|}
\hline Assignment $^{2}$ & DOX & $\begin{array}{l}\text { DOX- } \\
\text { FPIP }\end{array}$ & $\begin{array}{l}\text { DOX- } \\
\text { FMOR }\end{array}$ & EDOX & $\begin{array}{l}\text { EDOX- } \\
\text { FPIP }\end{array}$ & $\begin{array}{l}\text { EDOX- } \\
\text { FMOR }\end{array}$ & DNR & $\begin{array}{l}\text { DNR- } \\
\text { FPIP }\end{array}$ & $\begin{array}{l}\text { DNR- } \\
\text { FMOR }\end{array}$ & $\begin{array}{l}\text { DNR- } \\
\text { FHEX }\end{array}$ & $\begin{array}{l}\text { DNR- } \\
\text { OXZL }\end{array}$ & $\begin{array}{l}\text { DNR- } \\
\text { ON }\end{array}$ & EDNR & $\begin{array}{l}\text { EDNR- } \\
\text { FPIP }\end{array}$ & $\begin{array}{l}\text { EDNR- } \\
\text { FMOR }\end{array}$ \\
\hline & & $324(w)$ & $324(w)$ & $319(w)$ & $342(\mathrm{w})$ & $340(\mathrm{w})$ & & $324(w)$ & 330(w) & 330(w) & $324(w)$ & $330(w)$ & $330(w)$ & $330(w)$ & $335(w)$ \\
\hline $\begin{array}{c}\delta \text { Ring, } \omega \mathrm{\omega}-\mathrm{C}-\mathrm{O} \text { (a) } \\
{ }_{\mathrm{C}}-\mathrm{H}_{2}(\mathrm{a})\end{array}$ & $344(w)$ & $349(w)$ & $349(w)$ & - & - & - & $344(\mathrm{w})$ & $348(w)$ & $348(w)$ & $354(w)$ & $350(w)$ & $364(w)$ & - & - & - \\
\hline$\omega \mathrm{O}-\mathrm{H}^{\cdots} \mathrm{O}, \omega \mathrm{C}-\mathrm{H}$ & 444(s) & $440(\mathrm{~s})$ & $440(\mathrm{~s})$ & 444(s) & $438(\mathrm{~s})$ & $438(\mathrm{~s}$ & $439(\mathrm{~s})$ & $438(\mathrm{~s})$ & $440(\mathrm{~s})$ & 439(s) & $440(\mathrm{~s})$ & 436(s) & $441(\mathrm{~s})$ & $442(s)$ & $442(\mathrm{~s})$ \\
\hline $\begin{array}{c}\delta \text { Ring(phe), } \\
\omega \mathrm{C}-\mathrm{H}(\mathrm{d}), \delta \mathrm{C}=\mathrm{O} \text { (a) }\end{array}$ & $462(s)$ & - & - & $460(s)$ & $460(\mathrm{sh})$ & $465(\mathrm{~s})$ & $460(\mathrm{sh})$ & $460(\mathrm{~s})$ & - & $460(\mathrm{~s})$ & $461(\mathrm{~s})$ & $462(\mathrm{~s})$ & - & - & - \\
\hline $\begin{array}{c}\omega \mathrm{C}-\mathrm{OH}(\mathrm{a}), \omega \mathrm{C}-\mathrm{O}-\mathrm{C} \\
\text { (a-d) }\end{array}$ & $501(w)$ & $504(\mathrm{w})$ & $504(w)$ & $508(\mathrm{w})$ & $503(\mathrm{w})$ & $503(\mathrm{w})$ & $505(w)$ & $503(w)$ & $505(\mathrm{w})$ & $503(w)$ & $501(\mathrm{w})$ & $507(\mathrm{w})$ & $503(\mathrm{w})$ & $503(\mathrm{w})$ & $503(\mathrm{vw})$ \\
\hline $\begin{array}{c}\delta \text { Ring }(\mathrm{C}-\mathrm{H}), \omega \mathrm{C}- \\
\mathrm{H}(\mathrm{d}), \omega \mathrm{C}-\mathrm{H}_{3}(\mathrm{~d})\end{array}$ & 792(w) & $800(w)$ & $802(w)$ & - & - & - & 792(w) & 795(w) & 792(w) & 794(w) & 794(w) & - & - & - & - \\
\hline $\begin{array}{c}\mathrm{C}-\mathrm{H}_{2}(\mathrm{a}), \delta \mathrm{C}=\mathrm{O} \\
\delta \mathrm{C}-\mathrm{OH}(\mathrm{a})\end{array}$ & $990(w)$ & $990(w)$ & $990(w)$ & $990(w)$ & $990(w)$ & 995(w) & 990(w) & $990(w)$ & $990(w)$ & $990(w)$ & 990(w) & $987(w)$ & 990(w) & $993(w)$ & $985(w)$ \\
\hline $\begin{array}{l}\text { Ring breathing, } \\
\delta \mathrm{C}-\mathrm{H}(\mathrm{a}), \delta \mathrm{C}-\mathrm{C}-\mathrm{C} \text { (a) }\end{array}$ & 1083(m) & 1080(m) & $1083(\mathrm{~m})$ & $1081(\mathrm{~m})$ & $1081(\mathrm{~m})$ & $1081(\mathrm{~m})$ & 1083(m) & 1080(m) & $1083(\mathrm{~m})$ & $1083(\mathrm{~m})$ & $1083(\mathrm{~m})$ & $1083(\mathrm{~m})$ & $1081(\mathrm{~m})$ & $1081(\mathrm{~m})$ & 1081(m) \\
\hline $\begin{array}{c}\delta \mathrm{O}-\mathrm{H}^{\cdots} \mathrm{O} \text {, ring, } \\
\delta \mathrm{O}-\mathrm{H}(\mathrm{a})\end{array}$ & $1205(s)$ & $1210(\mathrm{~s})$ & $1192(s)$ & $1202(\mathrm{~s})$ & $1208(\mathrm{~s})$ & $1208(\mathrm{~s})$ & $1208(\mathrm{~s})$ & 1206(s) & $1208(\mathrm{~s})$ & $1205(\mathrm{~s})$ & $1205(\mathrm{~s})$ & $1203(\mathrm{~s})$ & $1208(\mathrm{~s})$ & $1208(\mathrm{~s})$ & $1208(s)$ \\
\hline $\begin{array}{c}\delta \mathrm{O}-\mathrm{H} \cdots \mathrm{O}(\mathrm{a}), \delta \mathrm{C}-\mathrm{O}- \\
\mathrm{H}(\mathrm{a}), \delta \mathrm{C}-\mathrm{H}\end{array}$ & $1235(s)$ & 1239(s) & $1243(\mathrm{~s})$ & $1237(\mathrm{~s})$ & $1244(s)$ & 1244(s) & $1237(\mathrm{~s})$ & $1233(\mathrm{~s})$ & $1237(\mathrm{~s})$ & $1243(\mathrm{~s})$ & $1233(\mathrm{~s})$ & $1240(\mathrm{~s})$ & $1237(\mathrm{~s})$ & $1240(\mathrm{~s})$ & $1239(\mathrm{~s})$ \\
\hline $\begin{array}{c}\delta \mathrm{O}-\mathrm{H} \cdots \mathrm{O} \text {, Ring, } \delta \mathrm{C}- \\
\text { OH }\end{array}$ & $1290(w)$ & $1298(w)$ & $1292(w)$ & $1284(\mathrm{w})$ & 1297(w) & $1296(w)$ & 1297(w) & $1290(w)$ & 1295(w) & 1291(w) & 1291(w) & 1291(w) & 1297(w) & 1300(w) & 1301(w) \\
\hline $\begin{array}{l}\text { Ring-O, Ring=O, } \\
\quad \delta \mathrm{C}-\mathrm{H}_{2}(\mathrm{~d})\end{array}$ & $1428(s)$ & - & $1426(\mathrm{~s})$ & $1428(\mathrm{~s})$ & - & $1434(\mathrm{~s})$ & - & $1413(\mathrm{~m})$ & - & $1436(\mathrm{~s})$ & $1413(\mathrm{~s})$ & - & - & - & - \\
\hline Ring, Ring-O, $\delta \mathrm{N}-\mathrm{H}$, & $1455(s)$ & 1444(s) & $1455(\mathrm{~s})$ & $1457(\mathrm{~s})$ & $1440(s)$ & $1455(\mathrm{~s})$ & 1444(s) & 1454(s) & 1440(s) & 1454(s) & 1455(s) & $1442(\mathrm{~s})$ & $1444(\mathrm{~s})$ & $1440(\mathrm{~s})$ & 1442(s) \\
\hline $\begin{array}{l}\text { Ring breathing, } \\
\text { ring(Phe), } \delta \mathrm{C}-\mathrm{H}(\text { aro) }\end{array}$ & 1579(m) & $1576(\mathrm{~m})$ & $1558(\mathrm{~m})$ & $1573(\mathrm{~m})$ & $1573(\mathrm{~m})$ & 1572(m) & $1575(\mathrm{~m})$ & $1580(\mathrm{~m})$ & 1570(m) & $1575(\mathrm{~m})$ & $1578(\mathrm{~m})$ & 1571(m) & 1573(m) & $1572(\mathrm{~m})$ & $1571(\mathrm{~m})$ \\
\hline Ring & $1643(w)$ & 1639(w) & 1639(w) & 1641(w) & 1637(w) & $1637(w)$ & 1641(w) & 1639(w) & $1637(w)$ & $1638(w)$ & $1638(w)$ & $1638(w)$ & $1641(w)$ & $1638(w)$ & $1640(w)$ \\
\hline
\end{tabular}

$v, \delta, \omega$, ou - belong to the stretching, bending, wagging vibrations

a- antraquinonepart,d-daunosamine part

$s, m, w$-strong, medium, weak intensity of bands 
Resonance Raman spectra obtained with the $488 \mathrm{~nm}$ laser for the solid state anthracyclines (Supplementary Materials, Figure 1S) are dominated by fluorescence. The maximum of the fluorescence in DOX Raman spectrum at $4140 \mathrm{~cm}^{-1}(611 \mathrm{~nm})$ corresponds to the maximum seen in DOX fluorescence spectra [27]. This maximum shifts to shorter wavelengths for EDOX, DNR-FPIP, DNR-FMOR and to higher wavelengths for the other investigated compounds. Resonance Raman spectrum of DOX ( $488 \mathrm{~nm}$ excitation wavelength) in water solution is, similarly, dominated by fluorescence (Supplementary Materials, Figure 2S).

This demonstrates a strong laser influence on the quality of Raman spectra of anthracyclines: characteristic Raman bands of the solid state anthracyclines are clearly observed in spectra recorded by using $785 \mathrm{~nm}$ laser (Figure 5). However, they are hardly seen when the $488 \mathrm{~nm}$ laser line is used as source due to the dominance of the fluorescence emission. On the other hand, both laser lines are suitable for in vitro investigation of anthracycline treated cells, as discussed in section 3.4.

\subsection{Tracking of doxorubicin in vitro}

The biological impact of DOX is broadly investigated and well described in literature, especially in the context of its interaction with DNA [26,29]. The impact on cells of DOX exposure has been assessed in various in vitro tests [14,17,48-50]. Spectroscopic methods have also been employed to study the interactions in vitro [25,51-53]. The development of a new therapeutic agent always involves a preclinical screening stage. During this stage, the pharmacodynamic, pharmacokinetic and toxicological properties of the candidate drug are analysed. The preclinical investigation is based on both in vitro models and in vivo experiments in various animal species [54]. However, due to regulatory developments in the EU [55], there is currently much promotion of the development of in vitro models, which can accurately indicate in vivo results $[56,57]$. In addition to ethical considerations and the $3 \mathrm{Rs}$ principle [58], animal drug testing has certain limitations. While different mammalian species share key physiological principles, they differ enough to be rather deficient for inter-species pharmacological and toxicological prediction [59]. There is, therefore, increasing emphasis on the development of in vitro tests as critical toxicological tools, capable of complementing and reducing animal testing, particularly at the preclinical screening phase of drug development.

The laser dependency of the spectroscopic properties (fluorescence/Raman) of anthracyclines, discussed in Section 3.3, is also evident when cells treated with DOX are 
investigated with two different excitation wavelengths. Previous work [60] demonstrated the utility of the Raman spectroscopy modality in the assessment of nuclear accumulation of four anthracyclines in endothelial cells when measurements were conducted with the use of the $488 \mathrm{~nm}$ laser line. The maximum of fluorescence for the anthracycline standards (3820-4245 $\mathrm{cm}^{-1}$, Figure 1S) coincides with the range in which the increased background is observed in the Raman spectra from anthracycline-treated cells, and, therefore, the fluorescence in this spectral range, observable as a background to the Raman spectrum, is a good marker for the presence of anthracycline in the cells. The integration of spectra obtained from the mapping allows the study of the distribution of the drug in the cell [60].

Investigations undertaken in the present work with the $785 \mathrm{~nm}$ laser line reveal similar information on the distribution of the drug, based, however, on the characteristic doxorubicin Raman marker bands [25] and both approaches are suitable for intracellular tracking of DOX at a subcellular level. However, spectra collected with the use of $785 \mathrm{~nm}$ source allow for more specific investigations of the modes of interaction of the drug, as, in the absence of the strong fluorescence background, the molecularly specific vibrational profiles of the drug itself as well as the biochemical environment of the cell can be monitored (Farhane et al. 2015b). On the other hand, for fast Raman imaging with better spatial resolution, application of the $488 \mathrm{~nm}$ laser line is preferable. Here, we present the comparison of spectra collected from cell compartments i.e. nucleus, nucleolus, cytoplasm of control and cells treated with DOX, using the $488 \mathrm{~nm}$ laser line as well as $785 \mathrm{~nm}$ (Figure 6). Highlighted regions correspond to DOX spectral features : $3820-4245 \mathrm{~cm}^{-1}$ (fluorescence region for the $488 \mathrm{~nm}$ laser line), 400-505 $\mathrm{cm}^{-1}$ and $1200-1290 \mathrm{~cm}^{-1}$ (characteristic bands for $785 \mathrm{~nm}$ laser line). 

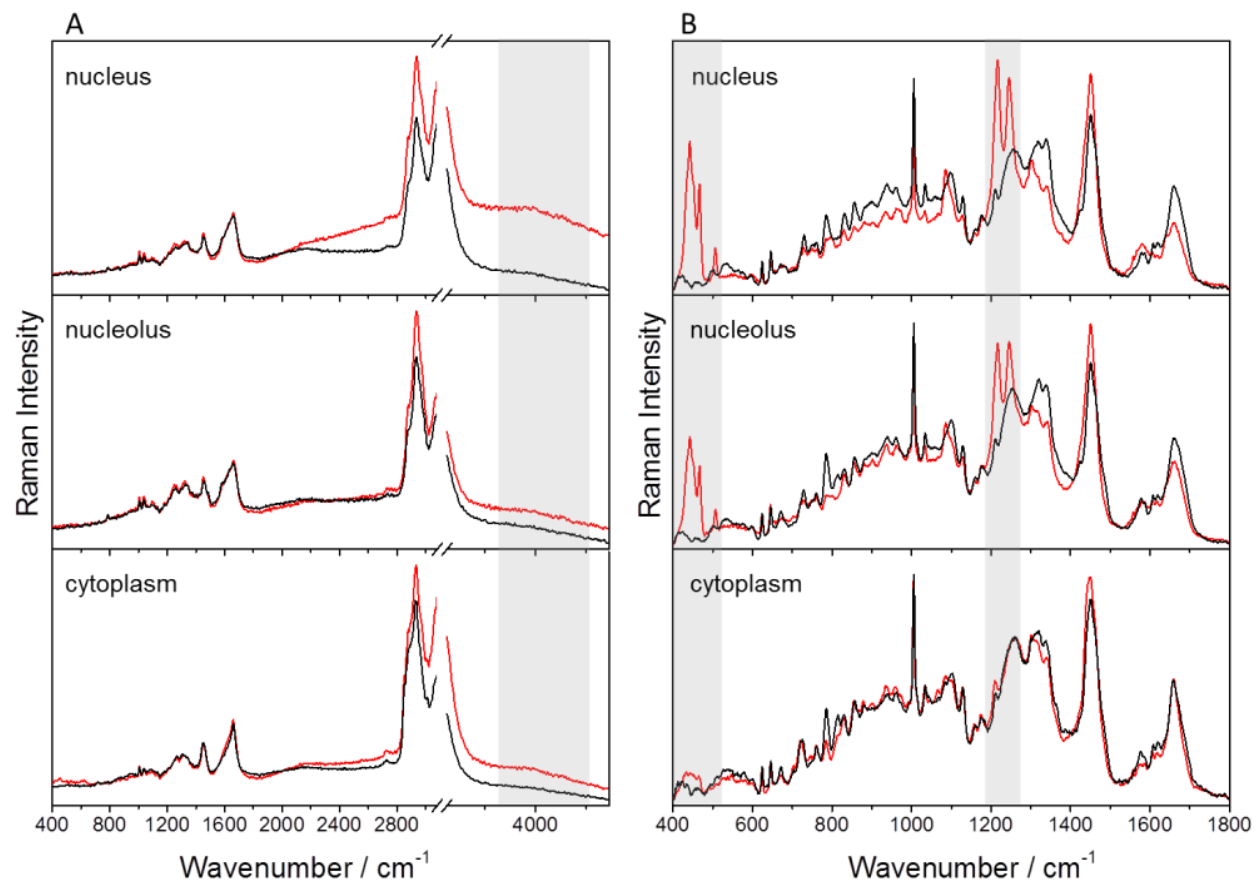

Figure 6. Raman spectra obtained from nucleus, nucleolus and cytoplasm of cells incubated with DOX, A: EA.hy926, with a source wavelength of $488 \mathrm{~nm} \mathrm{~B}$ : A549, with a source wavelength of $785 \mathrm{~nm}$; black: a control cell, red: a cell treated for $24 \mathrm{~h}$ with DOX $1 \mu \mathrm{M}$. Grey blocks show regions with characteristic DOX spectral features.

Raman investigations using both $488 \mathrm{~nm}$ and $785 \mathrm{~nm}$ laser lines confirm the predominant localization of DOX after 24hrs exposure in the nuclear region. Imaging of the fluorescence observed using $488 \mathrm{~nm}$ shows, however, that the intranuclear accumulation of DOX is not homogeneous over the whole nuclear area [60], potentially due to presence of transcriptionally active and inactive regions in the nuclear chromatin. Moreover, accumulation seems to be slightly higher in the nucleus itself than in the nucleoli. Notably, all spectra from treated cells, including those of the cytoplasm, seem to be affected by slightly increased background in comparison to the control. However, since fluorescence efficiency in general is extremely sensitive to local environment, the results provide more qualitative than quantitative information about presence of the drug in the cell. It should be further noted, that the presence of the enhanced background in the RR spectra of DOX affects strongly the level 
of signal to background ratio of the other Raman features and makes investigation of Raman spectra for DOX treated cells more complicated.

Although the use of the non-resonant $785 \mathrm{~nm}$ laser source does not provide the guidance of the distinctive DOX fluorescence as an indicator of the presence of the drug, the strong Raman marker bands in the fingerprint region provide unambiguous evidence of its presence, and those of the neighboring biochemical environment can provide further clues to the molecular interactions involved in, for example, receptor binding, and subsequent biochemical responses of the cell [Farhane et al. 2015b].

Analysis of the DOX Raman profiles at $785 \mathrm{~nm}$ confirms the predominant localization of the drug in the nuclear region; notably, significant, although lower contributions are present in the nucleolar regions. Previous in vitro studies showed the importance of nucleolus as a discriminative subcellular region between cancer cell lines [40] highlighting its importance not only in differentiating cancer cell lines but also as a major site of drug cellular effects such as DOX [25].

No evidence of DOX features in the cytoplasmic region of A549 cells was found, however, although comparison of the profiles of A549 cells and those of the human lung epidermoid carcinoma cell line, Calu-1, indicate that substantial DOX distribution in the cytoplasm can be found, and that this may be an indicator of the contribution of alternative modes of action of the drug, potentially the origin of the differing sensitivities/resistances of different cell lines to the drug (Farhane et al. 2016).

\section{Conclusions}

The potential of UV-vis and FT-IR spectroscopies for anthracycline characterization is presented. However, it is argued that Raman spectroscopy is the method of choice for antibiotic study both in the isolated form as well as after incubation with cells. We have demonstrated a strong laser influence on the quality of Raman spectra of anthracyclines. When the $488 \mathrm{~nm}$ laser is used, a strong fluorescence is recorded, but by using $785 \mathrm{~nm}$, characteristic bands of anthracyclines are clearly observed. On the other hand, both laser lines are suitable for in vitro investigation of anthracycline treated cells, although different levels of information are obtained when spectra collected from cell compartments (nucleus, nucleolus, cytoplasm) are analyzed. Ultimately, Raman spectroscopy provides a potential route towards in vitro screening of chemotherapeutic agents, to explore their uptake, nuclear accumulation interaction mechanisms, and subcellular distribution. 


\section{Acknowledgement}

This work was supported by National Center of Science (DEC-2013/08/A/ST4/00308). KM is supported by the Foundation for Polish Science (FNP) and National Science Center (grant DEC-2014/12/T/ST4/00686). ZF is supported by the Science Foundation Ireland, Principle Investigator Award 11/PI/1108.

\section{References}

[1] G. Minotti, P. Menna, E. Salvatorelli, G. Cairo, L. Gianni, Anthracyclines: molecular advances and pharmacologic developments in antitumor activity and cardiotoxicity., Pharmacol. Rev. 56 (2004) 185-229. doi:10.1124/pr.56.2.6.

[2] C.G. Grein A., Spalla C., di Marco A., Descrizione e classificazione di un attinomicete (Streptomyces peucetius sp. nova) produttore di una sostanza ad attività antitumorale: la daunomicina, G. Microbiol. 11 (1963) 109-118.

[3] C. Tan, H. Tasaka, K.-P. Yu, M.L. Murphy, D. a Karnofsky, Daunomycin, an antitumor antibiotic, in the treatment of neoplastic disease. Clinical evaluation with special reference to childhood leukemia, Cancer. 20 (1967) 333-353. doi:10.1002/1097-0142(1967)20:3<333::aid-cncr2820200302>3.0.co;2-k.

[4] A.Y. Chow, Anthracyclines Cause Endothelial Injury in Pediatric Cancer Patients: A Pilot Study, J. Clin. Oncol. 24 (2006) 925-928. doi:10.1200/JCO.2005.03.5956.

[5] R.B. Weiss, The anthracyclines: will we ever find a better doxorubicin?, Semin. Oncol. 19 (1992) 670-86.

[6] T. Wojcik, E. Szczesny, S. Chlopicki, Detrimental effects of chemotherapeutics and other drugs on the endothelium: A call for endothelial toxicity profiling., Pharmacol. Rep. 67 (2015) 811-7. doi:10.1016/j.pharep.2015.03.022.

[7] L.A. Smith, V.R. Cornelius, C.J. Plummer, G. Levitt, M. Verrill, P. Canney, et al., Cardiotoxicity of anthracycline agents for the treatment of cancer: systematic review and meta-analysis of randomised controlled trials., BMC Cancer. 10 (2010) 337. doi:10.1186/1471-2407-10-337.

[8] D.A. Gewirtz, A critical evaluation of the mechanisms of action proposed for the antitumor effects of the anthracycline antibiotics adriamycin and daunorubicin., 
Biochem. Pharmacol. 57 (1999) 727-41.

[9] F. Zunino, G. Capranico, DNA topoisomerase II as the primary target of anti-tumor anthracyclines., Anticancer. Drug Des. 5 (1990) 307-17.

[10] E. Ciesielska, K. Studzian, M. Wasowska, I. Oszczapowicz, L. Szmigiero, Cytotoxicity, cellular uptake and DNA damage by daunorubicin and its new analogues with modified daunosamine moiety., Cell Biol. Toxicol. 21 139-47. doi:10.1007/s10565-005-0142-1.

[11] S. Zhang, X. Liu, T. Bawa-Khalfe, L.-S. Lu, Y.L. Lyu, L.F. Liu, et al., Identification of the molecular basis of doxorubicin-induced cardiotoxicity., Nat. Med. 18 (2012) 163942. doi:10.1038/nm.2919.

[12] H. Cortés-Funes, C. Coronado, Role of anthracyclines in the era of targeted therapy., Cardiovasc. Toxicol. 7 (2007) 56-60. doi:10.1007/s12012-007-0015-3.

[13] F.M. Torti, M.M. Bristow, B.L. Lum, S.K. Carter, A.E. Howes, D.A. Aston, et al., Cardiotoxicity of Epirubicin and Doxorubicin : Assessment by Endomyocardial Biopsy Cardiotoxicity of Epirubicin and Doxorubicin : Assessment by Endomyocardial, (1986) $3722-3727$.

[14] S. Toldo, R.W. Goehe, M. Lotrionte, E. Mezzaroma, E.T. Sumner, G.G.L. BiondiZoccai, et al., Comparative cardiac toxicity of anthracyclines in vitro and in vivo in the mouse., PLoS One. 8 (2013) e58421. doi:10.1371/journal.pone.0058421.

[15] D.B. Sawyer, X. Peng, B. Chen, L. Pentassuglia, C.C. Lim, Mechanisms of Anthracycline Cardiac Injury: Can We Identify Strategies for Cardioprotection?, Prog. Cardiovasc. Dis. 53 (2010) 105-113. doi:10.1016/j.pcad.2010.06.007.

[16] D. Cardinale, A. Colombo, G. Lamantia, N. Colombo, M. Civelli, G. De Giacomi, et al., Anthracycline-Induced Cardiomyopathy. Clinical Relevance and Response to Pharmacologic Therapy, J. Am. Coll. Cardiol. 55 (2010) 213-220. doi:10.1016/j.jacc.2009.03.095.

[17] S. Wu, Adriamycin-induced Cardiomyocyte and Endothelial Cell Apoptosis: In Vitro and In Vivo Studies, J. Mol. Cell. Cardiol. 34 (2002) 1595-1607. doi:10.1006/jmcc.2002.2110.

[18] B.H. Trachtenberg, D.C. Landy, V.I. Franco, J.M. Henkel, E.J. Pearson, T.L. Miller, et al., Anthracycline-associated cardiotoxicity in survivors of childhood cancer, Pediatr. Cardiol. 32 (2011) 342-353. doi:10.1007/s00246-010-9878-3. 
[19] S.E. Lipshultz, S.D. Colan, R.D. Gelber, A.R. Perez-Atayde, S.E. Sallan, S.P. Sanders, Late cardiac effects of doxorubicin therapy for acute lymphoblastic leukemia in childhood., N. Engl. J. Med. 324 (1991) 808-815.

doi:10.1056/NEJM199103213241205.

[20] M. Wasowska, J. Wietrzyk, A. Opolski, J. Oszczapowicz, I. Oszczapowicz, Effect of structural modifications of anthracyclines on the ability to overcome drug resistance of cancer cells., Anticancer Res. 26 (2012) 2009-12.

[21] M. Stojak, L. Mazur, M. Opydo-Chanek, M. Łukawska, I. Oszczapowicz, Effects of structural modifications of daunorubicin on in vitro antileukemic activity, Anticancer Res. 32 (2012) 5271-5277.

[22] M. Wasowska, I. Oszczapowicz, J. Wietrzyk, A. Opolski, J. Madej, S. Dzimira, et al., Influence of the structure of new anthracycline antibiotics on their biological properties, Anticancer Res. 25 (2005) 2043-2048.

[23] M. Lukawska, J. Wietrzyk, A. Opolski, J. Oszczapowicz, I. Oszczapowicz, Synthesis and biological properties of oxazolinodaunorubicin-a new derivative of daunorubicin with a modified daunosamine moiety, Invest. New Drugs. 28 (2010) 600-608. doi:10.1007/s10637-009-9299-4.

[24] G. Das, A. Nicastri, M.L. Coluccio, F. Gentile, P. Candeloro, G. Cojoc, et al., FT-IR, Raman, RRS measurements and DFT calculation for doxorubicin, Microsc. Res. Tech. 73 (2010) 991-995. doi:10.1002/jemt.20849.

[25] Z. Farhane, F. Bonnier, A. Casey, H.J. Byrne, Raman micro spectroscopy for in vitro drug screening: subcellular localisation and interactions of doxorubicin, Analyst. 140 (2015) 4212-4223. doi:10.1039/C5AN00256G.

[26] L. Angeloni, G. Smulevich, M.P. Marzocchi, Absorption, fluorescence and resonance Raman spectra of adriamycin and its complex with DNA, Spectrochim. Acta Part A Mol. Spectrosc. 38 (1982) 213-217. doi:10.1016/0584-8539(82)80199-2.

[27] M. Manfait, L. Bernard, T. Theophanides, Resonance and pre-resonance Raman spectra of the antitumor drugs adriamycin and daunomycin, J. Raman Spectrosc. 11 (1981) 68-74. doi:10.1002/jrs.1250110205.

[28] K.W. Hillig, M.D. Morris, Pre-resonance Raman spectra of adriamycin, Biochem. Biophys. Res. Commun. 71 (1976) 1228-1233. doi:10.1016/0006-291X(76)90785-3.

[29] A. Beljebbar, G.D. Sockalingum, J.F. Angiboust, M. Manfait, Comparative FT SERS, resonance Raman and SERRS studies of doxorubicin and its complex with DNA, 
Spectrochim. Acta Part A Mol. Spectrosc. 51 (1995) 2083-2090. doi:10.1016/05848539(95)01515-7.

[30] N. Strekal, A. German, G. Gachko, A. Maskevich, S. Maskevich, The study of the doxorubicin adsorbed onto chemically modified silver films by surface-enhanced spectroscopy, J. Mol. Struct. 563-564 (2001) 183-191. doi:10.1016/S00222860(01)00512-9.

[31] J. Gautier, E. Munnier, L. Douziech-Eyrolles, A. Paillard, P. Dubois, I. Chourpa, SERS spectroscopic approach to study doxorubicin complexes with $\mathrm{Fe}(2+)$ ions and drug release from SPION-based nanocarriers., Analyst. 138 (2013) 7354-61. doi:10.1039/c3an00787a.

[32] C. Eliasson, A. Lorén, K.V.G.K. Murty, M. Josefson, M. Käll, J. Abrahamsson, et al., Multivariate evaluation of doxorubicin surface-enhanced Raman spectra, Spectrochim. Acta Part A Mol. Biomol. Spectrosc. 57 (2001) 1907-1915. doi:10.1016/S13861425(01)00453-X.

[33] I. Manet, F. Manoli, B. Zambelli, G. Andreano, A. Masi, L. Cellai, et al., Affinity of the anthracycline antitumor drugs Doxorubicin and Sabarubicin for human telomeric G-quadruplex structures., Phys. Chem. Chem. Phys. 13 (2011) 540-551. doi:10.1039/c0cp00898b.

[34] H. Huang, Q. Yuan, J.S. Shah, R.D.K. Misra, A new family of folate-decorated and carbon nanotube-mediated drug delivery system: Synthesis and drug delivery response, Adv. Drug Deliv. Rev. 63 (2011) 1332-1339. doi:10.1016/j.addr.2011.04.001.

[35] X. Yang, X. Zhang, Z. Liu, Y. Ma, Y. Huang, Y. Chen, High-efficiency loading and controlled release of doxorubicin hydrochloride on graphene oxide, J. Phys. Chem. C. 112 (2008) 17554-17558. doi:10.1021/jp806751k.

[36] C.J. Lee, J.S. Kang, M.S. Kim, K.P. Lee, M.S. Lee, The study of doxorubicin and its complex with DNA by SERS and UV-resonance Raman spectroscopy, Bull. Korean Chem. Soc. 25 (2004) 1211-1216. doi:10.5012/bkcs.2004.25.8.1211.

[37] M. Baranska, ed., Optical Spectroscopy and Computational Methods in Biology and Medicine, Springer Netherlands, Dordrecht, 2014. doi:10.1007/978-94-007-7832-0.

[38] E. Zuser, T. Chernenko, J. Newmark, M. Miljković, M. Diem, Confocal Raman microspectral imaging (CRMI) of murine stem cell colonies., Analyst. 135 (2010) 3030-3033. doi:10.1039/c0an00546k.

[39] J.W. Chan, D.S. Taylor, T. Zwerdling, S.M. Lane, K. Ihara, T. Huser, Micro-Raman 
Spectroscopy Detects Individual Neoplastic and Normal Hematopoietic Cells, Biophys. J. 90 (2006) 648-56. doi:10.1529/biophysj.105.066761.

[40] Z. Farhane, F. Bonnier, A. Casey, A. Maguire, L. O'Neill, H.J. Byrne, Cellular discrimination using in vitro Raman micro spectroscopy: the role of the nucleolus., Analyst. 140 (2015) 5908-19. doi:10.1039/c5an01157d.

[41] C. Matthäus, T. Chernenko, J.A. Newmark, C.M. Warner, M. Diem, Label-free detection of mitochondrial distribution in cells by nonresonant Raman microspectroscopy., Biophys. J. 93 (2007) 668-73. doi:10.1529/biophysj.106.102061.

[42] K. Majzner, K. Kochan, N. Kachamakova-Trojanowska, E. Maslak, S. Chlopicki, M. Baranska, Raman imaging providing insights into chemical composition of lipid droplets of different size and origin: in hepatocytes and endothelium., Anal. Chem. 86 (2014) 6666-74. doi:10.1021/ac501395g.

[43] H.H. Lin, Y.C. Li, C.H. Chang, C. Liu, A.L. Yu, C.H. Chen, Single nuclei Raman spectroscopy for drug evaluation, Anal. Chem. 84 (2012) 113-120. doi:10.1021/ac201900h.

[44] H. Nawaz, F. Bonnier, P. Knief, O. Howe, F.M. Lyng, A.D. Meade, et al., Evaluation of the potential of Raman microspectroscopy for prediction of chemotherapeutic response to cisplatin in lung adenocarcinoma., Analyst. 135 (2010) 3070-6. doi:10.1039/c0an00541j.

[45] Y. Nonaka, Comparative Study of Aclacinomycin Versus Adriamycin by Means of Resonance Raman Spectroscopy, 21 (1990) 133-141.

[46] Q. Yan, W. Priebe, J.B. Chaires, R.S. Czernuszewicz, Interaction of doxorubicin and its derivatives with DNA: Elucidation by resonance Raman and surface-enhanced resonance Raman spectroscopy, Biospectroscopy. 3 (1997) 307-316. doi:10.1002/(SICI)1520-6343(1997)3:4<307::AID-BSPY6>3.0.CO;2-0.

[47] B. Kann, H.L. Offerhaus, M. Windbergs, C. Otto, Raman microscopy for cellular investigations - From single cell imaging to drug carrier uptake visualization, Adv. Drug Deliv. Rev. 89 (2015) 71-90. doi:10.1016/j.addr.2015.02.006.

[48] T. Wojcik, E. Buczek, K. Majzner, A. Kolodziejczyk, J. Miszczyk, P. Kaczara, et al., Comparative endothelial profiling of doxorubicin and daunorubicin in cultured endothelial cells., Toxicol. In Vitro. 29 (2015) 512-21. doi:10.1016/j.tiv.2014.12.009.

[49] T. Murata, H. Yamawaki, R. Yoshimoto, M. Hori, K. Sato, H. Ozaki, et al., Chronic effect of doxorubicin on vascular endothelium assessed by organ culture study., Life 
Sci. 69 (2001) 2685-2695. doi:10.1016/S0024-3205(01)01352-2.

[50] M.A. Ivi, S.D. Petrovi, E. Kalmán, T. Milosavljevi, I. Reljin, AFM studies of DNA structures extracted from adriamycin treated and non-treated Ehrlich tumor cells, 70 (2005) 823-831.

[51] M. Manfait, T. Theophanides, Fourier transform infrared spectra of cells treated with the drug adriamycin., Biochem. Biophys. Res. Commun. 116 (1983) 321-6. doi:10.1017/CBO9781107415324.004.

[52] T.J. Moritz, D.S. Taylor, D.M. Krol, J. Fritch, J.W. Chan, Detection of doxorubicininduced apoptosis of leukemic T-lymphocytes by laser tweezers Raman spectroscopy., Biomed. Opt. Express. 1 (2010) 1138-1147. doi:10.1364/BOE.1.001138.

[53] J. Guo, W. Cai, B. Du, M. Qian, Z. Sun, Raman spectroscopic investigation on the interaction of malignant hepatocytes with doxorubicin., Biophys. Chem. 140 (2009) 57-61. doi:10.1016/j.bpc.2008.11.005.

[54] E.F.. Brandon, C.D. Raap, I. Meijerman, J.H. Beijnen, J.H.. Schellens, An update on in vitro test methods in human hepatic drug biotransformation research: pros and cons, Toxicol. Appl. Pharmacol. 189 (2003) 233-246. doi:10.1016/S0041-008X(03)00128-5.

[55] European Union, Directive 2010/63/EU of the European Parliament and of the Council of 22 September 2010 on the protection of animals used for scientific purposes., Off. J. Eur. Union. (2010) 33-79. doi:32010L0063.

[56] H.J. Byrne, M. Baranska, G.J. Puppels, N. Stone, B. Wood, K.M. Gough, et al., Spectropathology for the next generation: quo vadis?, Analyst. 140 (2015) 2066-73. doi:10.1039/c4an02036g.

[57] X. Diao, K.B. Scheidweiler, A. Wohlfarth, S. Pang, R. Kronstrand, M.A. Huestis, In Vitro and In Vivo Human Metabolism of Synthetic Cannabinoids FDU-PB-22 and FUB-PB-22., AAPS J. 18 (2016) 455-64. doi:10.1208/s12248-016-9867-4.

[58] W. Russel, R. Burch, The principles of humane experimental technique, Methuen, London. (1959).

https://scholar.google.com/scholar?q=The+Principles+of+Humane+Experimental+Tec hnique\#1 (accessed March 26, 2016).

[59] P. Jennings, "The future of in vitro toxicology"., Toxicol. In Vitro. 29 (2015) 1217-21. doi:10.1016/j.tiv.2014.08.011. 
[60] K. Majzner, T. Wojcik, E. Szafraniec, M. Lukawska, I. Oszczapowicz, S. Chlopicki, et al., Nuclear accumulation of anthracyclines in the endothelium studied by bimodal imaging: fluorescence and Raman microscopy, Analyst. 140 (2015) 2302-2310. http://xlink.rsc.org/?DOI=C4AN01882F. 


\section{Supplementary}

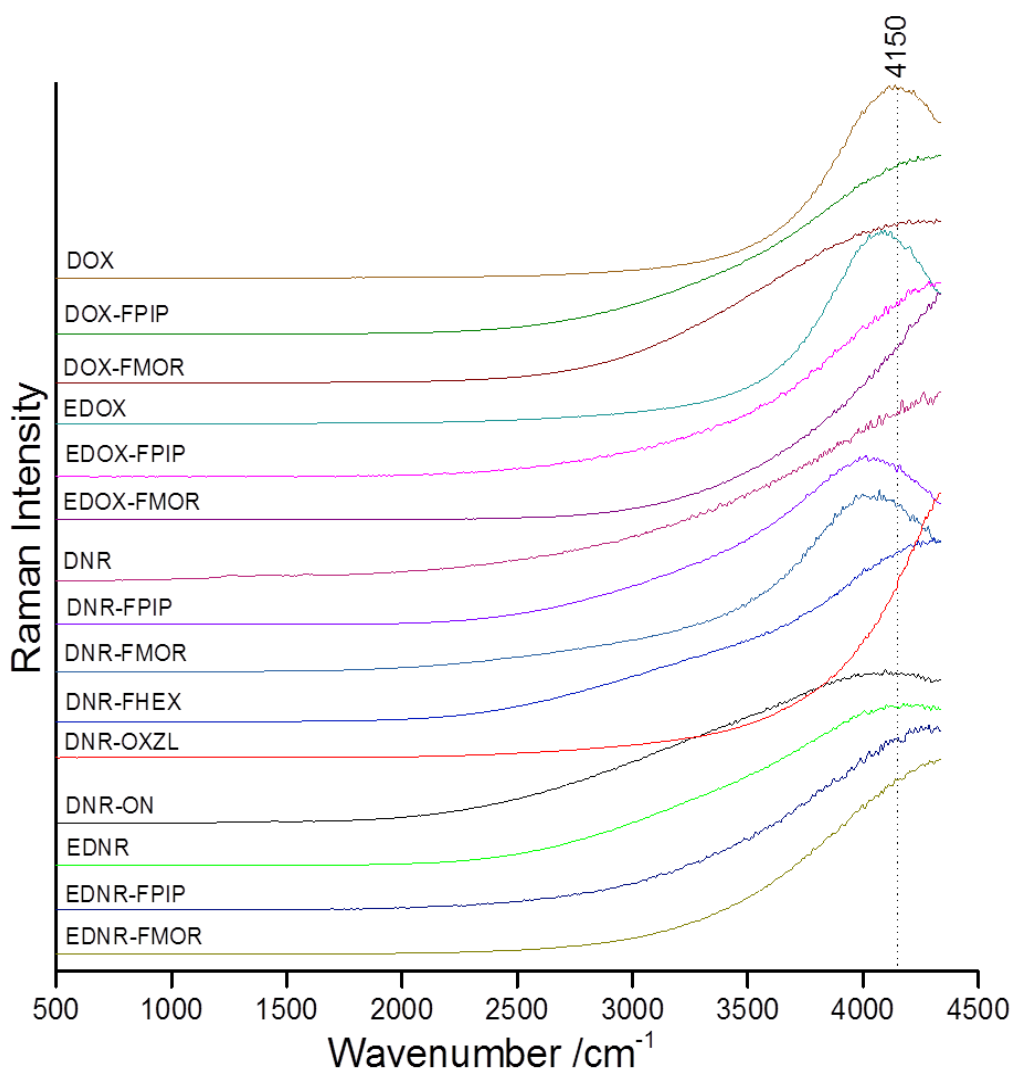

Figure 1S. Raman spectra of anthracyclines in the liquid state (488 nm laser excitation). 


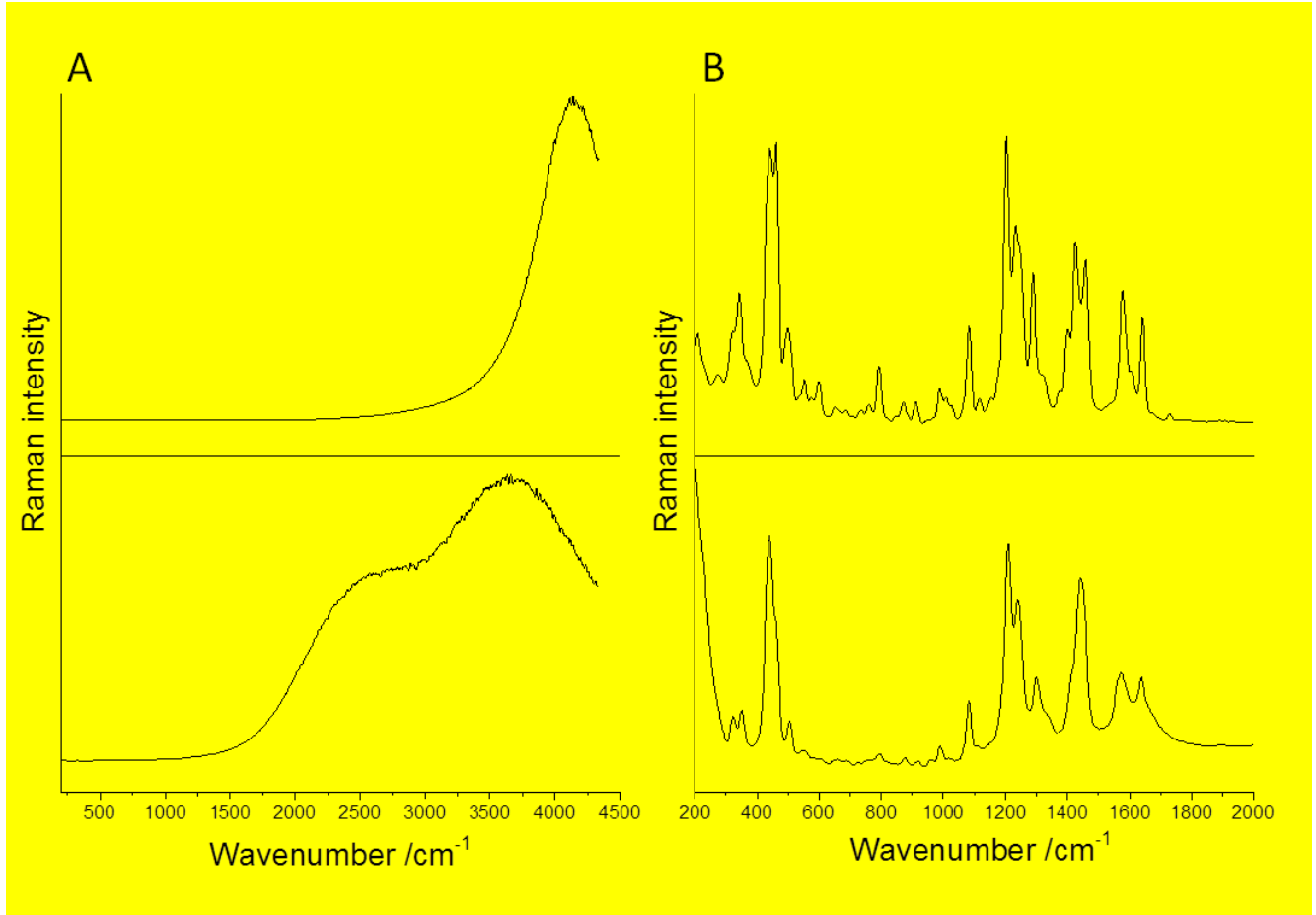

Figure 2S. Comparison of Raman spectra of DOX , A: $488 \mathrm{~nm}$ excitation wavelength, B: 785 nm excitation wavelength, top panel: solid state DOX, bottom panel: liquid state DOX. 